\title{
Response of Sunnhemp (Crotalaria juncea L.) to Sowing Time and Topping for Seed Production
}

\author{
Foram Patel*, P. H. Patel, Rutul Patel and Dolly Gelot \\ Department of Agronomy, C. P. College of Agriculture, Sardarkrushinagar Dantiwada \\ Agricultural University, Sardarkrushinagar - 385 505, Gujarat, India \\ *Corresponding author
}

Keywords

Sunnhemp, Sowing time, Topping, Seed and stalk yield

Article Info

Accepted:

25 May 2021

Available Online:

10 June 2021
A field experiment entitled "Response of sunnhemp (Crotalaria juncea L.) to sowing time and topping for seed production" was conducted during kharif 2016 at C. P. College of Agriculture, S. D. Agricultual University, Sardarkrushinagar. The experiment consisted of four different dates of sowing and four stages of topping at different intervals. These treatments were evaluated under split plot design with four replications. Among various dates of sowing, treatment $S_{2}$ ( $4^{\text {th }}$ week of June) exhibited significantly higher plant height, branches per plant, higher number of pods per plant, test weight, seed and stalk yield, net return $(25,213$ ₹/ha) and benefit : cost ratio (1.97). Among various topping treatments, treatment $\mathrm{T}_{2}$ (topping at $30 \mathrm{DAS}$ ) gave significantly higher number of branches per plant, number of pods per plant, test weight, seed and stalk yield, net realization $(23,484$ ₹/ha) and benefit : cost ratio (1.89).

\section{Introduction}

Sunnhemp (Crotalaria juncea L.), is cultivated as multipurpose legume especially for its fine fibre in many countries including India. The crop is also grown as a fodder crop. The genus name "Crotalaria" means 'rattle' and refers to the noise made by the seeds when the mature pods are shaken. Species of this genus are wide spread throughout tropical, sub-tropical and to a lesser extent temperate countries. This crop is native to India. It is known in India by various names like 'Shan' (Gujarati) 'Sonai' or 'San' (Hindi), 'Sanpat' (Bengali), 'Tag' (Marathi), 'Vakku' (Malayalam), 'Janumu' (Telegu), 'Saab' (Kannada).

Among various cultural practices, proper time of sowing is a prerequisite. Climatic factors such as temperature, duration of bright sunshine and relative humidity differs with sowing time of the crop, which ultimately influence the yield of sunnhemp and also 
sowing date is a very important parameter in crop production. The optimum sowing date paves the way for better use of time, light, temperature, precipitation and other factors. Slight variation in the temperature may cause complete crop failure or low yield and productivity. It is therefore essential to adjust the sowing time such a way to provide optimum soil and atmospheric temperature required for better growth and development of the crop. Topping practice greatly influences the growth and yield attributes in sunnhemp. Apical bud pinching helps in altering the source-sink relationship by curbing the vegetative growth and hastening reproductive phase. It also helps in production of side shoots or branches thus resulting in increased photosynthetic activity and accumulation of more photosynthates ultimately resulting in increased seed size and yield.

\section{Materials and Methods}

The investigation was conducted during kharif, 2016 at Agronomy Instructional Farm, Department of Agronomy, Chimanbhai Patel College of Agriculture, Sardarkrushinagar Dantiwada Agricultural University, Sardarkrushinagar, District : Banaskantha (Gujarat). The experiment consisted of four different times of sowing and four stages of topping at different intervals and treatments were evaluated under split plot design with four replications.

The main plot treatments comprised of sowing times viz; $3^{\text {rd }}$ week of June $\left(\mathrm{S}_{1}\right), 4^{\text {th }}$ week of June $\left(\mathrm{S}_{2}\right), 1^{\text {st }}$ week of July $\left(\mathrm{S}_{3}\right)$ and $2^{\text {nd }}$ week of July $\left(\mathrm{S}_{4}\right)$ and sub plot treatments were comprised of topping stages viz; no topping $\left(\mathrm{T}_{1}\right)$, topping at 30 DAS $\left(\mathrm{T}_{2}\right)$, topping at 45 DAS $\left(\mathrm{T}_{3}\right)$ and topping at $60 \mathrm{DAS}\left(\mathrm{T}_{4}\right)$. The soil of the experimental field was loamy sand in texture, low in organic carbon and available nitrogen, medium in available phosphorus and potash content. Electrical conductivity (EC) was very low. Seeds were sown in the field with the spacing of $45 \mathrm{~cm} \mathrm{x} 10 \mathrm{~cm}$ apart at a seed rate of $15 \mathrm{~kg} / \mathrm{ha}$ and watered immediately. The crop was provided with phosphorous and nitrogen in the form of DAP and urea at the rate of 20:40:00 NPK kg/ha respectively. Standard intercultural practices were carried out as and when required. The crop was irrigated at an interval of 10-12 days. Data were recorded for various growth and yield parameters like plant height $(\mathrm{cm})$, nodules per plant, dry weight of nodules per plant (mg), branches per plant, pods per plant, pod length $(\mathrm{cm})$, seeds per pod and test weight (g). The crop was threshed plot wise and seed and straw yield were obtained from net plot which were converted into $\mathrm{kg} / \mathrm{ha}$ and analyzed statistically. While calculating gross return, prevalent market price for sale of sunnhemp seed was taken as Rs $45 / \mathrm{kg}$ and price for sale of sunnhemp straw was considered as Rs $2 / \mathrm{kg}$. Net return was calculated by deducting cost of cultivation from gross income and benefit/cost ratio was calculated by dividing total cost of cultivation (Rs/ha) by gross return (Rs/ha).

\section{Results and Discussion}

\section{Effect of sowing time}

The results reveal that time of sowing influenced different growth parameters significantly. Significantly higher value of growth attributes viz., plant height at harvest $(252.3 \mathrm{~cm})$ and number of branches per plant (5.1) and yield attributes viz., number of pods per plant (35.0) and test weight (5.38 g) were recorded under $4^{\text {th }}$ week of June $\left(\mathrm{S}_{2}\right)$ sown crop due to the availability of sufficient time and favourable environment for vegetative growth and development in case of the early sown crop as compared to delayed sowing. 
Table.1 Effect of sowing time and topping on plant height $(\mathrm{cm})$, number of root nodules, dry weight of root nodules, number of branches per plant, number of pods per plant and length of pod $(\mathrm{cm})$ of sunnhemp

\begin{tabular}{|c|c|c|c|c|c|c|}
\hline Treatments & $\begin{array}{c}\text { Plant } \\
\text { height } \\
\text { at harvest } \\
(\mathrm{cm})\end{array}$ & $\begin{array}{c}\text { Number of } \\
\text { root } \\
\text { nodules per } \\
\text { plant }\end{array}$ & $\begin{array}{l}\text { Dry weight of } \\
\text { root nodules } \\
\text { per plant } \\
\text { (mg) }\end{array}$ & $\begin{array}{l}\text { Number of } \\
\text { branches } \\
\text { per plant }\end{array}$ & $\begin{array}{l}\text { Number } \\
\text { of pods } \\
\text { per plant }\end{array}$ & $\begin{array}{l}\text { Length of } \\
\operatorname{pod}(\mathrm{cm})\end{array}$ \\
\hline \multicolumn{7}{|c|}{ Sowing time (S) (Main-Plot) } \\
\hline$S_{1}: 3^{\text {rd }}$ week of June & 244.1 & 9.32 & 304.6 & 4.9 & 33.0 & 2.97 \\
\hline$S_{2}: 4^{\text {th }}$ week of June & 252.3 & 9.77 & 314.4 & 5.1 & 35.0 & 3.12 \\
\hline$S_{3}: 1^{\text {st }}$ week of July & 246.7 & 9.40 & 305.4 & 4.8 & 31.9 & 2.99 \\
\hline$S_{4}: 2^{\text {nd }}$ week of July & 172.3 & 9.40 & 301.9 & 4.6 & 30.5 & 3.01 \\
\hline S.Em \pm & 5.24 & 0.25 & 6.17 & 0.09 & 0.94 & 0.06 \\
\hline C.D. at $5 \%$ & 16.8 & NS & NS & 0.29 & 3.01 & NS \\
\hline C.V.\% & 9.16 & 10.5 & 8.04 & 7.55 & 11.55 & 7.39 \\
\hline \multicolumn{7}{|c|}{ Topping (T) (Sub- Plot) } \\
\hline$T_{1}:$ No topping & 242.9 & 10.42 & 325.2 & 4.5 & 29.0 & 3.00 \\
\hline$T_{2}:$ Topping at 30 DAS & 208.2 & 8.92 & 296.5 & 5.3 & 35.1 & 3.08 \\
\hline$T_{3}:$ Topping at 45 DAS & 229.7 & 9.11 & 298.3 & 5.0 & 33.7 & 3.05 \\
\hline $\mathrm{T}_{4}:$ Topping at $60 \mathrm{DAS}$ & 235.7 & 9.44 & 306.3 & 4.7 & 32.6 & 2.97 \\
\hline S.Em \pm & 2.60 & 0.20 & 4.40 & 0.08 & 0.88 & 0.05 \\
\hline C.D. at $5 \%$ & 7.45 & 0.58 & 12.6 & 0.24 & 2.53 & NS \\
\hline C.V.\% & 4.54 & 8.50 & 5.75 & 6.96 & 10.81 & 6.20 \\
\hline
\end{tabular}

Table.2 Effect of sowing time and topping on number of seeds per pod, test weight $(\mathrm{g})$, seed yield, straw yield (kg/ha) and harvest index of sunnhemp

\begin{tabular}{|c|c|c|c|c|c|}
\hline Treatments & $\begin{array}{c}\text { Number of seeds } \\
\text { per pod }\end{array}$ & $\begin{array}{c}\text { Test weight } \\
\text { (g) }\end{array}$ & $\begin{array}{l}\text { Seed yield } \\
\text { (kg/ha) }\end{array}$ & $\begin{array}{c}\text { Straw yield } \\
\text { (kg/ha) }\end{array}$ & $\begin{array}{c}\text { Harvest index } \\
(\%)\end{array}$ \\
\hline \multicolumn{6}{|c|}{ Sowing time (S) (Main-Plot) } \\
\hline$S_{1}: 3^{\text {rd }}$ week of June & 8.14 & 4.58 & 619 & 7465 & 7.74 \\
\hline$S_{2}: 4^{\text {th }}$ week of June & 8.39 & 5.38 & 797 & 7604 & 9.68 \\
\hline $\mathrm{S}_{3}: \mathbf{1}^{\text {st }}$ week of July & 8.26 & 4.76 & 731 & 6597 & 10.05 \\
\hline$S_{4}: 2^{\text {nd }}$ week of July & 8.00 & 5.01 & 709 & 4016 & 15.06 \\
\hline S.Em \pm & 0.14 & 0.13 & 14.7 & 197 & 0.28 \\
\hline C.D. at $5 \%$ & NS & 0.41 & 47.2 & 631 & 0.90 \\
\hline C.V.\% & 6.74 & 10.5 & 8.27 & 12.3 & 11.0 \\
\hline \multicolumn{6}{|c|}{ Topping $(\mathrm{T})$ (Sub- Plot) } \\
\hline$T_{1}:$ No topping & 8.27 & 4.58 & 683 & 5639 & 11.30 \\
\hline $\mathrm{T}_{2}$ : Topping at $30 \mathrm{DAS}$ & 8.41 & 5.29 & 784 & 7352 & 10.51 \\
\hline $\mathrm{T}_{3}$ : Topping at $45 \mathrm{DAS}$ & 7.99 & 4.98 & 703 & 6407 & 10.44 \\
\hline $\mathrm{T}_{4}:$ Topping at $60 \mathrm{DAS}$ & 8.11 & 4.88 & 686 & 6285 & 10.27 \\
\hline S.Em \pm & 0.11 & 0.12 & 13.1 & 131 & 0.27 \\
\hline C.D. at $5 \%$ & NS & 0.35 & 37.8 & 377 & NS \\
\hline C.V.\% & 5.44 & 10.0 & 7.38 & 8.19 & 10.3 \\
\hline
\end{tabular}

The results were in line with those reported by Yadav (2003) for kharif cowpea, Hari Ram et al., (2011) in pigeon pea, Singh et al., (2011) in uradbean and Awasarmal et al., (2015) in greengram. 
Various sowing time exerted significant effect on seed and straw yield of sunn hemp. $4^{\text {th }}$ week of June sown crop recorded significantly higher seed yield $(797 \mathrm{~kg} / \mathrm{ha})$ and straw yield $(7604 \mathrm{~kg} / \mathrm{ha})$. Harvest index was significantly the highest in $2^{\text {nd }}$ week of July $\left(\mathrm{S}_{4}\right)$ sown crop. This might be due to realization of minimum straw yield with treatment $\mathrm{S}_{4}$ because of delayed in sowing which ultimately increased the harvest index. The results were in conformity with those of Hari Ram et al., (2011) in pigeonpea, Singh et al., (2011) in urdbean and Awasarmal et al., (2015) in greengram.

\section{Effect of topping}

Taller plants were registered with no topping practice which might be due to the fact that plants were not topped and as such plants grew to their original height without reduction. Maximum value of number of root nodules (10.42) and dry weight of root nodules $(325.2 \mathrm{mg})$ per plant were recorded with no topping $\left(\mathrm{T}_{1}\right)$.

The number and dry weight of nodules per plant considerably decreased with early topping due to suppressed shoot and root growth as the topping practices enhanced branching and checked root and shoot growth which resulted in less number and dry weight of root nodules per plant. Topping practice on 30 DAS $\left(T_{2}\right)$ had recorded more number of branches per plant (5.3) since topping resulted in arresting vertical growth and stimulated shoot axillary buds and improved the side branches. The results were in accordance to the results obtained by Kandagatla (2013) in fenugreek.

Yield attributing characters viz. number of pods per plant (35.1), length of pod $(3.08 \mathrm{~cm})$, number of seeds per pod (8.41) and test weight $(5.29 \mathrm{~g})$ were recorded significantly higher under topping at 30 DAS. Seed yield $(784 \mathrm{~kg} / \mathrm{ha})$ and straw yield $(7352 \mathrm{~kg} / \mathrm{ha})$ were also recorded significantly higher under topping at 30 DAS. This might be due to topping at proper stage (30 DAS) had helped in maximum translocation of assimilates which ultimately resulted in maximum number of branches per plant and pods per plant which in turn increased the seed and straw yield. Similar results have been reported by Kumar (2010) in field bean, Kandagatla (2013) in fenugreek, More et al., (2005) in Jute and Sowmya et al., (2017) in fenugreek. Harvest index of sunnhemp was not affected significantly by different topping treatments.

It was recapitulated from the study that when sunnhemp was sown for seed production on $4^{\text {th }}$ week of June coupled with topping at 30 DAS $\left(S_{2} T_{2}\right)$ secured higher seed yield.

\section{References}

Awasarmal, V. B.; Vyavahare, S. P. and Pawar, S. U. (2015). Performance of greengram as influenced by sowing time and levels of fertilizer. International Journal of Tropical Agriculture. 33 (2) : 891-895.

Hari, Ram.; Singh, G.; Sekhon, H. S.; Gill, K. K. and Khanna, V. (2011). Effect of sowing time on the performance of pigeonpea genotypes. Journal of Food Legumes. 24 (3) : 207-210.

Kandagatla, Sandeep (2013). Effect of cutting management and sulphur application on growth, yield and quality of fenugreek (Trigonella foenumgraecum L.). M.Sc. (Horti.) thesis (Unpublished). Dr. Y.S.R. Horticultural University, Rajendranagar, Hyderabad.

Kumar, Sudeep (2010). Influence of nipping and hormonal spray on seed yield and quality in field bean [Lablab Purpureus (L.) Sweet] genotypes. M.Sc. (Agri.) thesis (Unpublished). University of Agricultural Sciences, 
Dharwad.

More, S. R.; Rajmane, S. B.; Surana, P. P. and Mehetre, S. S. (2005). Effect of dates of sowing and topping on seed production of jute (Corchorus spp.). Seed Research. 33 (1) : 20-23.

Singh, G.; Hari, Ram.; Sekhon, H. S.; Gill, K. K. and Khanna, V. (2011). Effect of time of planting on nodulation, growth and seed yield of kharif urdbean genotypes. Journal of Food Legumes. 25 (2) : 125-127.

Sowmya, P. T.; Veerbhadreshwar, H. H.; Naruka, I. S. and Shaktawat, R. P. S. (2017). Standardisation of date of sowing and stage of pinching on fenugreek yield and quality parameters. International Journal of Agricultural Sciences. 7 (3) : 12821286.

USDA-NRCS (2009). 'Tropic Sun' sunnhemp release brochure. Hoolehua Plant Materials Center, Molokai, HI. http://www.plantmaterials.nrcs.usda.gov/pubs/hipmcrb8 433.pdf (accessed on 31 Aug. 2016).

Yadav, G. L. (2003). Effect of sowing time, row spacing and seed rate on yield of cowpea under rainfed condition. Indian Journal of Pulses Research. 16 (2) : 157-158.

\section{How to cite this article:}

Foram Patel, P. H. Patel, Rutul Patel and Dolly Gelot. 2021. Response of Sunnhemp (Crotalaria juncea L.) to Sowing Time and Topping for Seed Production. Int.J.Curr.Microbiol.App.Sci. 10(06): 710-714. doi: https://doi.org/10.20546/ijcmas.2021.1006.078 